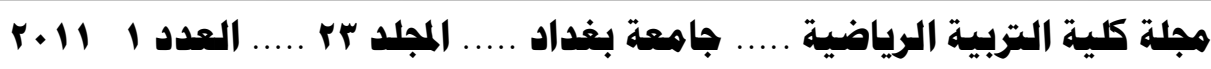

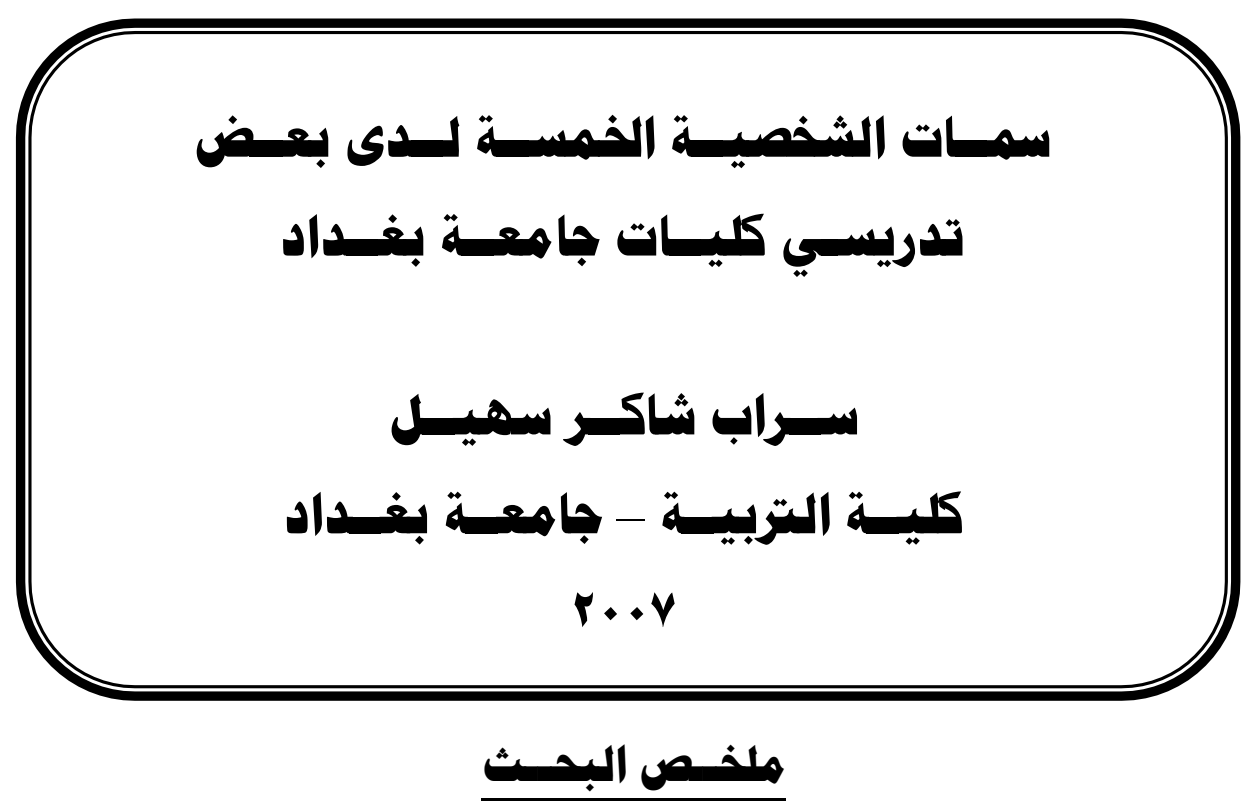

اهتمــت دول العـالم بالعمليـة التريويـة لأهميتهـا في حركـة المجتمعـات ـ ويالتـالي تفجيـر الطاقات الكامنة وتطوير القدرات الإبداعية للأفراد ومنهم تدريسي الجامعة كونهم الركيزة في عملية التعلم وعبر تأثير سماتهم الشخصية وتكمن مشكلة البحث في تشخيص نقاط القوة والضعف في شخصية تدريسي بعض كليات جامعة بغداد في ضوء استخدام أحدث مقاييس الشخصية وهدفت الدراسة الى التعرف على الفروق بين السمات لاى بعض تدريسي كليات جامعة ، أمسا فروض البحث فهو وجود فروق ذات دلالـة معنوية بين السمات الشخصية لاى بعض تلريسي كليات جامعة بغداد . وتكونت عينة البحث من (9 7) تدريسي وزع عليهم القياس المستخدم في قياس الثخصية وتوصل الباحث الى تمتع تدريسيو كلية التربية الرياضية والصيدلة والتربية بنات ، بســات الانفتـاح ، صـوة الضـمير ، الانبسـاطية ، الانسـجام ، وهـي مؤثـرات إيجابيـة للصحة النفسية . لصنية كمـا تميز تلريسيو كليـات التربيـة الرياضية ، الصيلئة ، التربيـة بنـات بسمتي الانبساطية والانسجام 


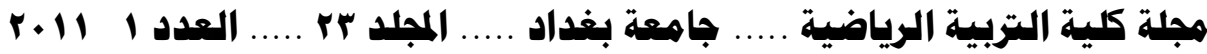

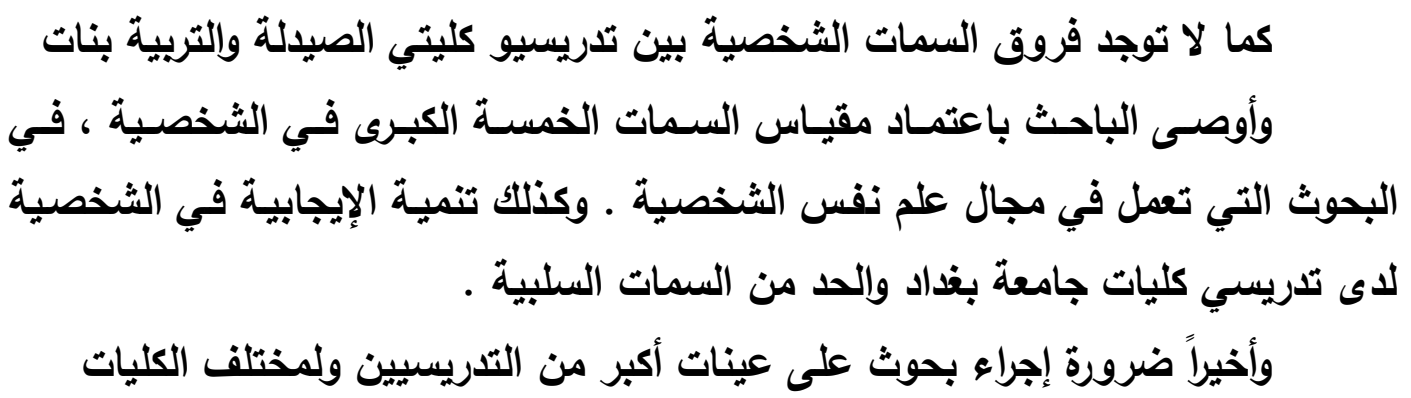

The Five personality Traits Dome College Instructors of the University of Baghdad

The world is interests in education to its great importance in the development of any country. Education can fire the potential energy and develop creative abilities in individuals such as college instructors. An instructor is the center of the leaning process and students are affected by personality traits whether good or bad. The problem of the research lies in diagnosing the weaknesses and strengths in college instructors' personalities. The aim of the study is to identify the differences among personality traits in some college instructors in the university of the research is that there are significant statistical differences among personality traits in some college instructors in the University in the University of Baghdad .

The subjects of the study were (69) college instructor taken from most colleges in the university of Baghdad, The researcher concluded that instructors from the colleges of physical education, pharmacy, education for women all share conscience, openness harmony which are all positive indicators of psychological health . He also concluded that there are no differences in personality traits between instructors of the college of pharmacy and the college of education for women.

The researcher recommended using personality traits measurement for measuring the five major personality traits. He also recommended improving personality traits and limiting negative traits. Finally he recommended making similar researches on larger subjects from different colleges . 


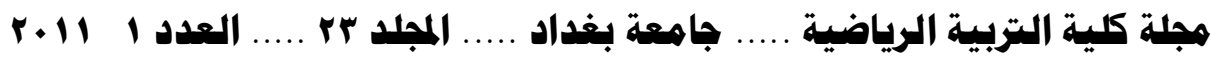

\section{البـاب الأول}

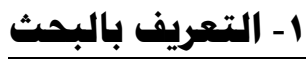

1-1 المقدهة وأهمية البحث

إن تولي معظم دول العالم المتقدمة أو النامية في العصر الحالي الـى العملية التريويـة

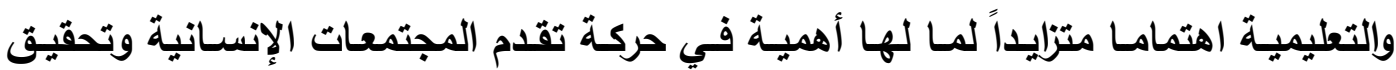
الأهداف في شتـى مجالات الحياة وذلكك من خـلال تفجير الطاقـات الكامنـة وتطوير كافـة القدرات الإبداعية فضلاً عن بناء الثخصية لاى تدريسي الجامعات بصورة صحيحة كونهم

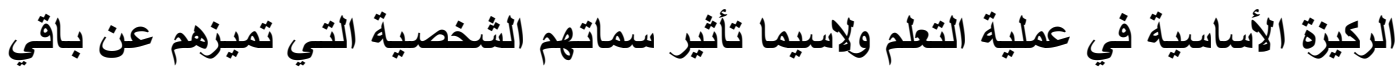

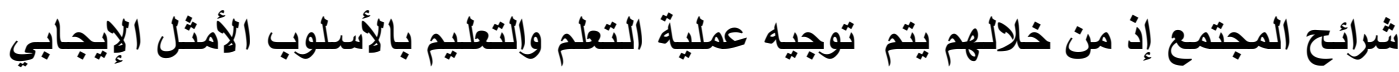

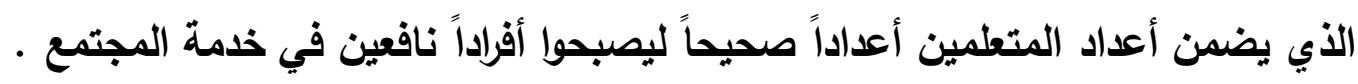

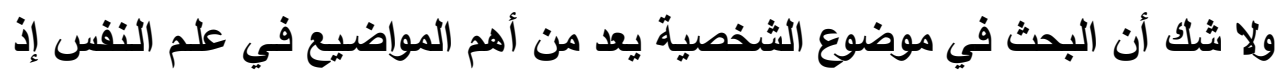

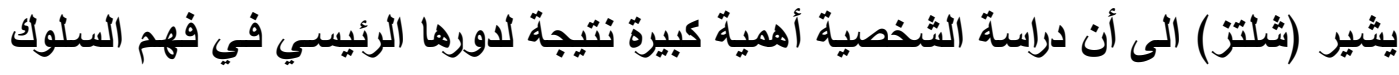

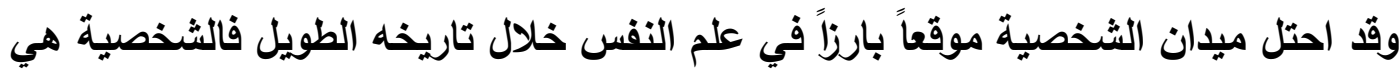

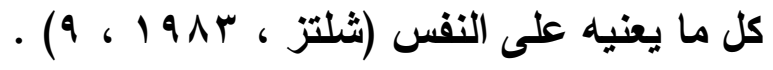

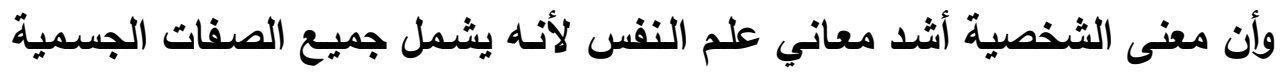

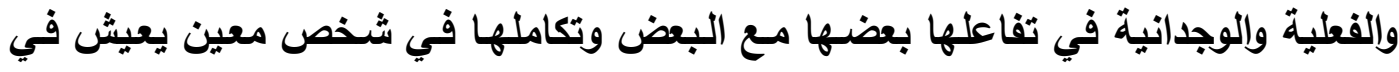

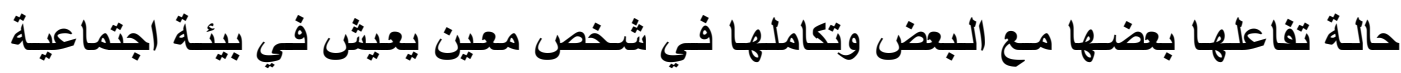
معينة ومن هذا فإن ستانجر (Stanger) يرى بأن الثخصية الإنسانية أكبر ظاهرة درسها

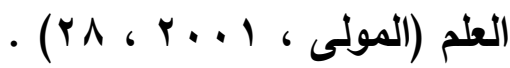
وعليه فإن الدراسة في مجال الثخصية من حيث نموها وتركيبها وأبعادها يساعد في التنبؤ بما سيكون عليه سلوك الفرد في موقف معين حتى يمكن ضبطه والتحكم فيه

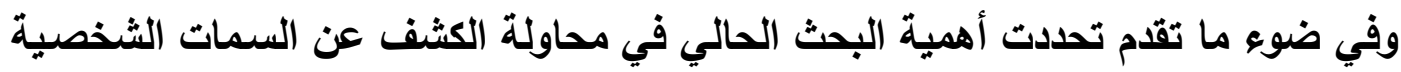




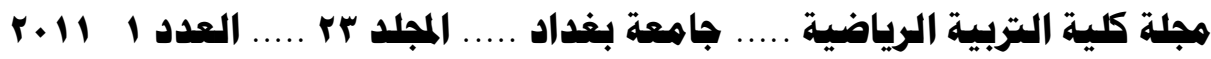

لاى عينة من تدريسي جامعة بغداد وهنا يؤكد (Popkins) الى أن التعرف على السمات الشخصصية ريمـا تضعنا أمسام مهمـة التفكير في معالجة الكثير مـن المشكلات المرتبطة بالصحة النفسية ومستوى الإنجاز لاسيما في الوسط الجامعي (مصطفى ، ه . . ب ، 1 \&)

فضـلاً عـن اســخدام نمـوذج السـمات الخمسـة الكبـرى في الشخصسية يعـد مـن التوجيهات المعاصرة في تحليل وقياس السمات الشخصية ويشير هنا (Lahey) الحى أن هذا النمـوذج بـأ يستخدم مـن قبل الباحثين المعاصرين بحيث أصبح لديهم قناعة بأنسه يعطي وصفاً كاملاً لأبعاد الشخصية (Lahey, 2001 , 461) .

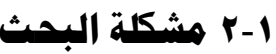

تعد دراسـة الشخصية الإنسـانية من أصسب المواضيع بحثاً واختبـاراً لأنها تتعلق بسلوكيات الإنسان التي تتجم عن مجمل التفاعلات بين تكوينه الوراثي وتكوينه المكتسب على جميع الأصعدة الاجتماعيـة والثقافية واللدينيـة والسياسية والاقتصـادية ويهذا انتهج العلماء أساليب متعددة في دراسـة الشخصية كل بما يتناسب مع أغراض دراسته ويمرور الزمن فقد عرضت نمـاذج عديدة ومتنوعة من مقيـاس الشخصية ولاسيما علمـاء النفس الأين بحثوا في موضوع السمات إذ قدموا العديد من السمات التي يمكن قياسـها بواسطة طرق مختلفة ومن هنا تمكن مشكلة البحث الحالي في تثخيص نقاط القوة والضعف في شخصية عينة من تدريسي بعض الكليات في جامعة بغداد في ضوء استخدام أحد أحدث المقاييس المستخدمة في الشخصية فضـلاً عن أن هذه الشريحة لهـا أهمية كبيرة ودور فعال في المجتمع إذ تعد نخبة علمية ومعرفية متميزة لا تنصب أهدافهم في سياق العطاء العلمي ولكن في تربية أجيال من الشباب يحملون شخصية متميزة في المستقبل .

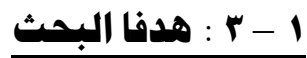


1 - r - 1 : التعرف على الفروق بين السمات الشخصية للدى بعض تدريسي كليات

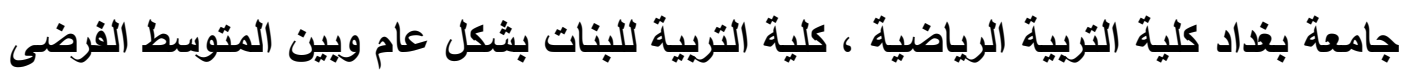

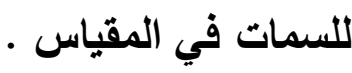

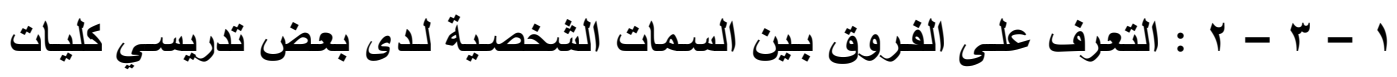

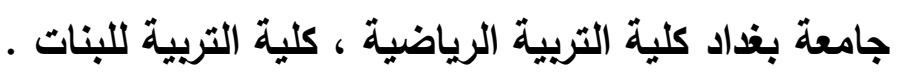

1 - 1 : : فرضا البحث 1

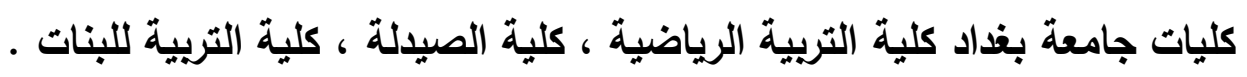

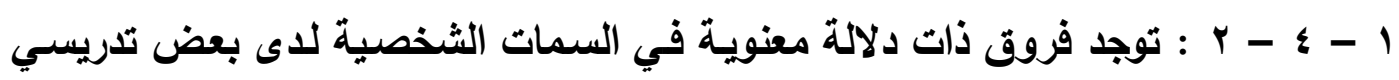

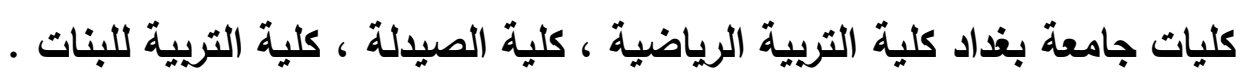
1 - 0 : هجالات البحث 1 - 1 - 1 - 1 : المجال البشري : بعض تلدريسي كليات جامعة بغداد كلية التربية الرياضية ، كلية الصيدلة ، كلية التربية للبنات .

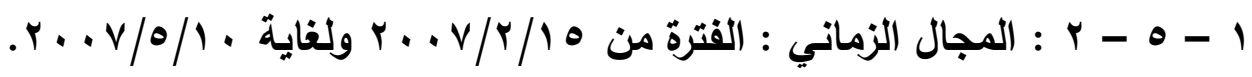

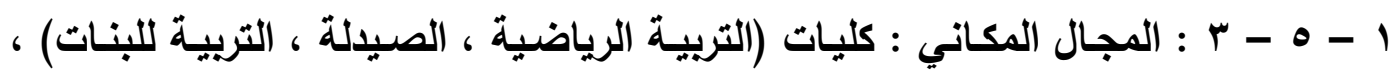

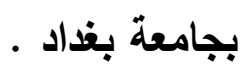


هبلة كلية التربية الرياضية .... جاهعة بغداد .... المبلد r. .... العدد ا

إت 1 - 1

السمات والعوامل "الخمس الكبرى في الشخصية :

هـي محاولـة لتصـنيف سـمات الشخصسية السى خمسـة عوامسل كبـرى وهـي (العصـابية ، والانبسـاطية ، والانفتـاح ، والانسـجام ، وصـحة الضـير) · \& Costa)

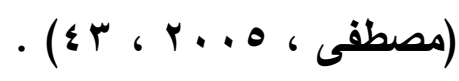
تعريف الإصطات :

اـ الشخصية : بأنها التظيم الديناميكي داخل الفرد للأجهزة النفسية الجسمية التي تعزز الطابع الفريد للشخص في السلوك والتفكير • r. العصـابية : Neuroticism - N أصحابها يميلـون الصى الضـغوط النفسية والأفكار الغير واقعيـة ومفرطون في الرغبـات ولحوحون ولديهم اسـتجابات غير موفقة في التعامل. r. الانبساطية : Extraversion - E يتصف أصحابها بشدة التفاعل الثخصسي في العلاقات ويمستوى جيد من الفعالية والتحفيز ولايهم القدرة على التمتع • ع. الانفتاح : Openness - 0 : بفاعلية مسبقة للبحث ويتقدير الخبرات من أجل ذاتها والقدرة على التحمل واستكثاف الأثثياء غير المألوفة . ه. الانسجام : Agreeableness - A يشير الحى توجهات الاجتماعية فعالـة ، وينتقل من يتصف بـه على خط متصل من العطف والرحمـة الحى الخصومة في الأفكار والمشاعر والأفعال .

(") كلمة العوامل تثثير الى أنه جاء جراء التحليل العاملي الذي قام به كل من العالمين (كوستا وماكوى) على مقياس الثخصية . 


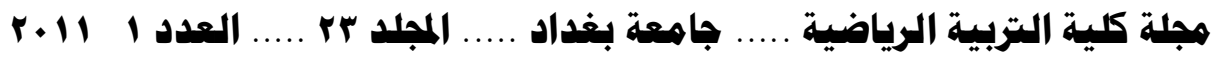

4. صحوة الضمير : Consciientiousness - Cيتحدد بلرجـة عاليـة مـن

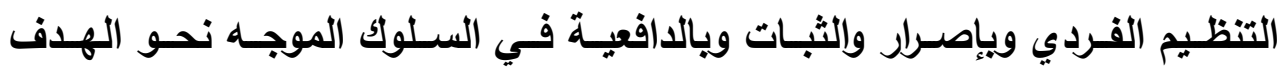

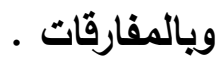

البــاب الثانـي

r r 1 - الإطار النظرية

r 1 - 1 - مدخل الى هفهوم الشخصية

تعد الثخصية من الموضوعات التي يصعب الاتفاق التام على تحديد مفهومها

بثكل دقيق وذلك لتناول دراستها من زوايا متعددة ، عليه لا يوجد تعريف موحد مقبول من

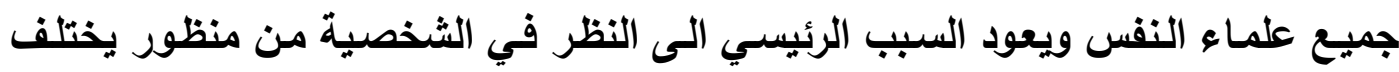

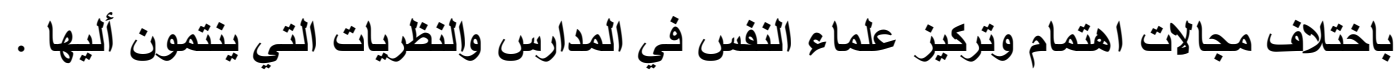

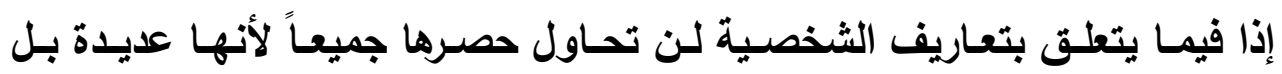

سنحاول استعراض بعض التعاريف التي تقودنا الى تكوين فهم واضح للثخصية .

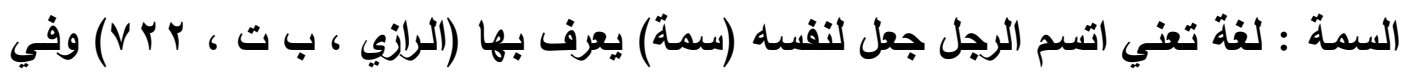
مصطلحات علم النفس تعني مظهر ثابت نسبياً من مظاهر السلوك أو بعد السلوك (عاقل ،

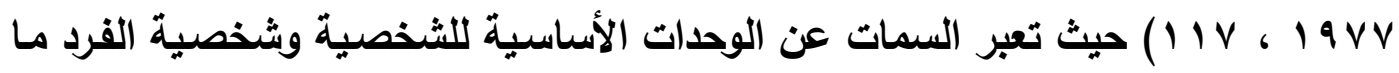

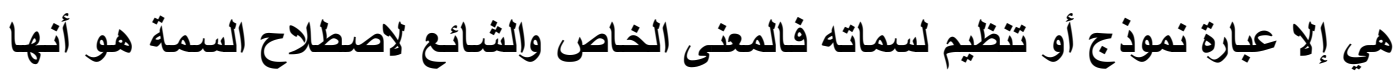

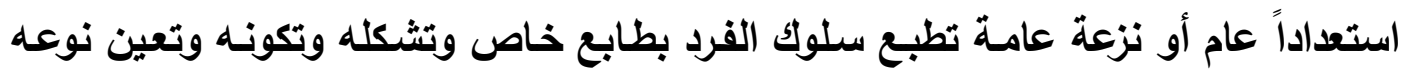

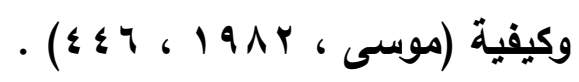

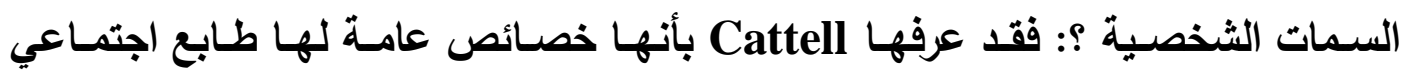
انفعالي يمكن عن طريق القياس الصحيح ملاحظة احتلاف الفرد عن الآخر.

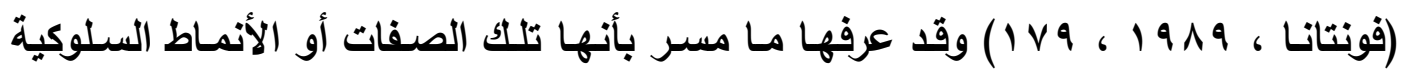

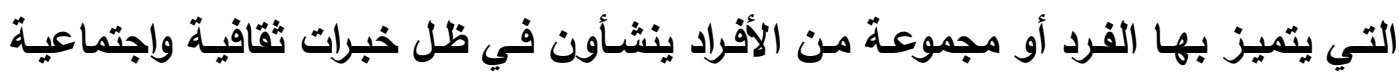




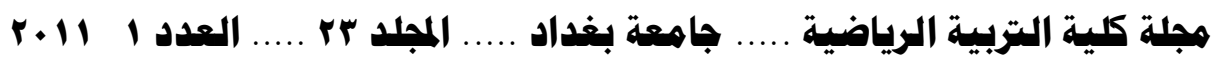

معينة (مامسر ، 01919 ، ع 19 ) أما مراد فقد عبر عنها في تعريفه أنها قيمة سلوكية لها صفة الثبات النسى في المواقف الرياضية لدى الرياضي اللاعب والتي عن طريقها يتميز

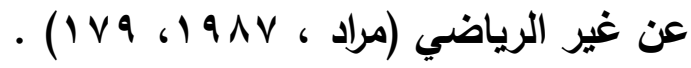
إذ يعرف Allprt الثخصية بأنها التنظيم الايناميكي داخل الفرد للأجهزة النفسية الجسمية

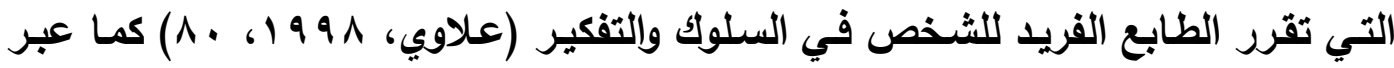
Cattell موقف معين ما (يونس، 999 199، 9) ويرى Burt أن الثخصية هي ذلكاء النظام الكامل

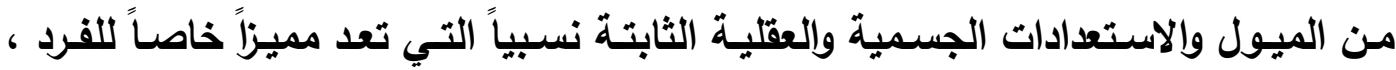
والتي يتحدد بمقتضاها أسلويه الخاص في التكيف ميع البيئة المادية والاجتماعية (السلوم

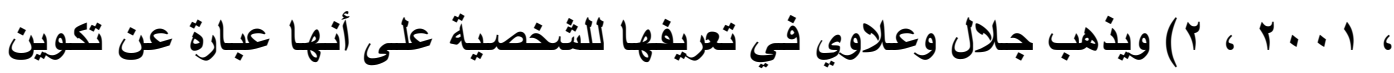
فسيولوجي ونفس واجتماعي يتضمن عمليات اجتماعية كما يتضمن عمليات نفسية فضلاً

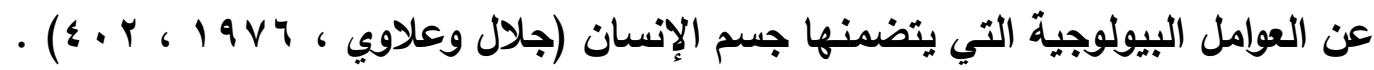

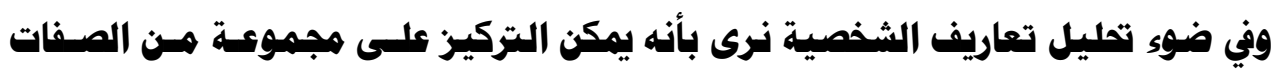

والثصائص الآتية : وفئ 1 - الثخصية شيء مجرد غير ملموس أو محسوس وفي غاية التعقيا . r - تتضمن الثخصية مكونـات وعناصر عديدة جسمية ونفسية وإنفعالية وشعورية ولا شعورية ذاتية وييئية . r - تتصف الثخصية بنوع من الثات أو الاستقرار النسبي ومـع ذلك فالثخصية دينامية متطورة لأن الفرد يعيش ويواجه ظروفاً متغيرة ممـا يتطلب تعديل شخصية وسلوكه بمـا

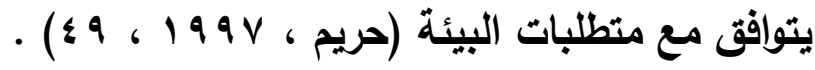

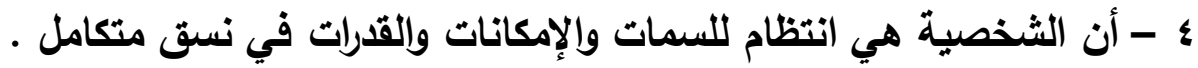

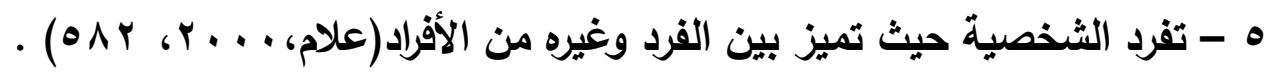




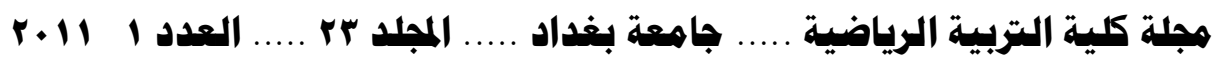

7 - أن الشخصية تشمل التفاعلات بين الأنماط السلوكية والتغيرات الداخلية التي تحدث الفرد من جهة والمثيرات الخارجية من جهة أخرى (القيسى ، 99 V 19 ، 1 ( ) ويضيف (أبو البو جادو) أنتا نستطيع أن تقوم بأن كل إنسان يشبه كل الناس من جهة ويعض الناس من

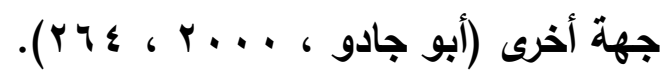

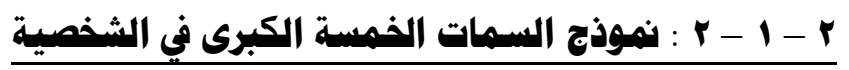

يعتقد معظم الباحثين أن الأبعاد التي قدمها إيزنـك هامـة ولكنهـا لا تفسر القصـة كاملة للشخصية ، ويعد كوستا وماكرية رائدين في فتح المجال أمسام الكثيرين من الباحثين للاقتناع بوجود خمسة إبعاد في الثخصية اهتديا إلبها بمنهج التحليل العالمي ، أمـا أبعاد أو عناصر هذا النموذج الذي يدعى نموذج الخمسة الكبار (Big - Five model) أو يو نموذج الخمسة عوامل (Five - factor model) فهي الانفتاح والضمير والانبسـاط والموافق والعصابية (الوقفى، 99 1 1، ب9 ه ه). 


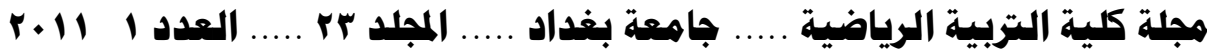

\section{جدول (1)}

أوصاف العوامل الخمسة الكبرى في الشخصية

\begin{tabular}{|c|c|c|}
\hline أدنى الارجات المسجلة & الأوصاف الشـاملة للأبعاد & أعلى درجات المسجلة \\
\hline 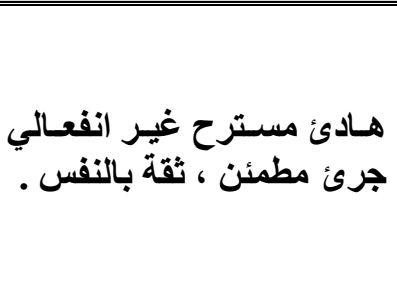 & 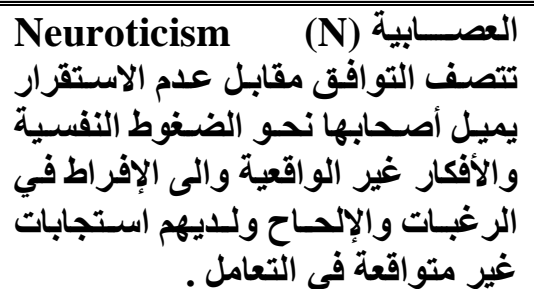 & 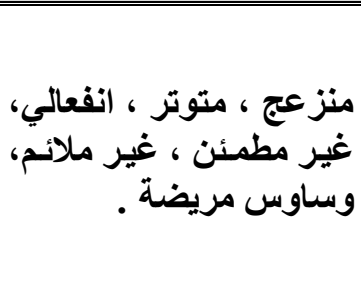 \\
\hline 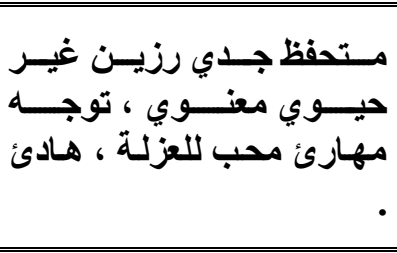 & 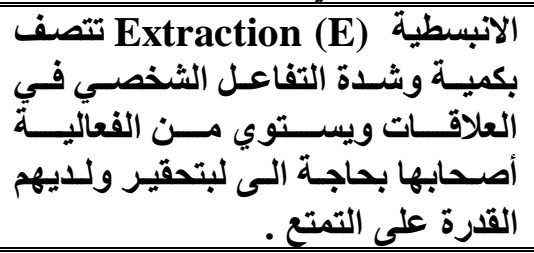 & 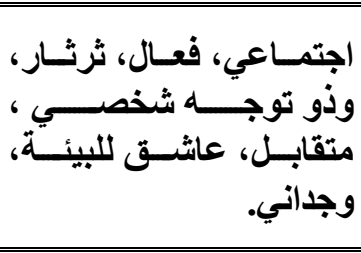 \\
\hline 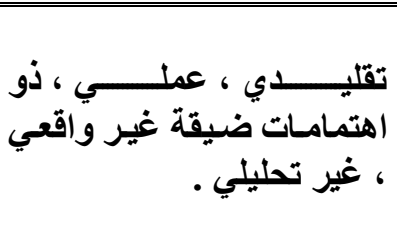 & 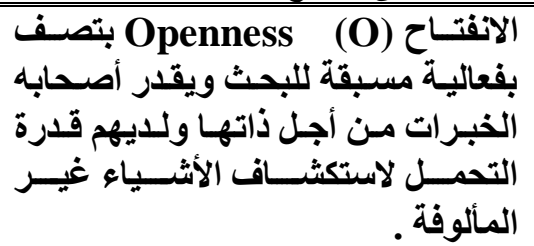 & 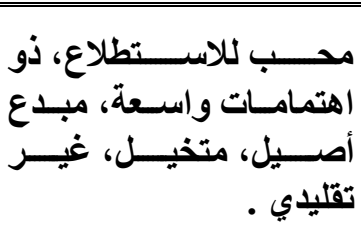 \\
\hline 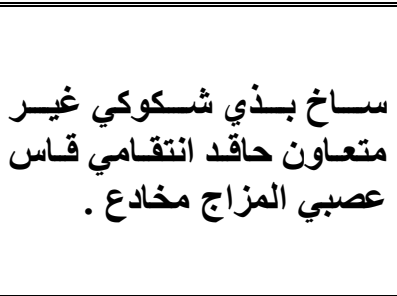 & 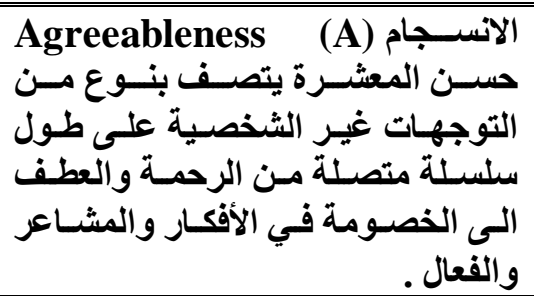 & 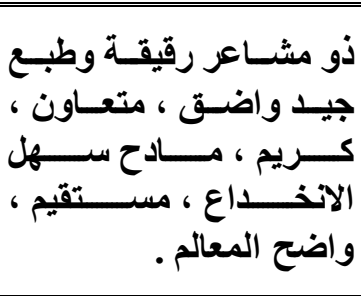 \\
\hline 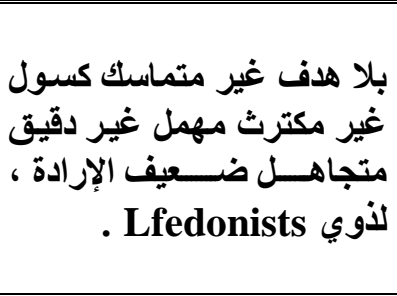 & 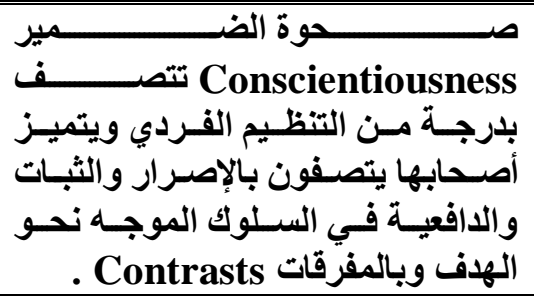 & 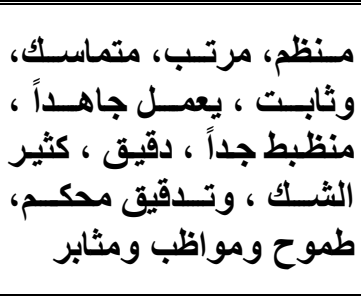 \\
\hline
\end{tabular}

( $)$ ( مصطقى ، $)$ 


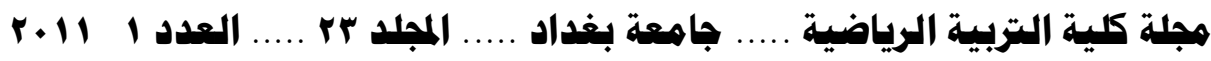

وفي سباق آخر من الدراسـات المعتمدة على البحوث الرائدة في هذا المجال لكل من كوستا وماك كراي (Costa \& Mc Crae , 1992) وجد كل من ويكنز وتروينيل (Wiggens \& Tropnell , 1997) الكبرى في الشخصية هي كالآتي : 1 - الانفتـاح على التجـارب : يشـير السى أن صـاحبة ذو اهتمامسات فنيـة وجدى ومخيل

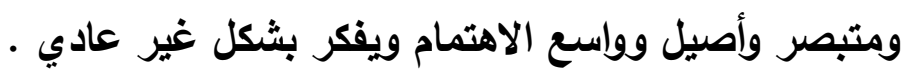

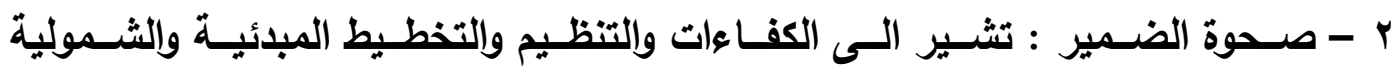
والاستقلالية ودمائة الخلق والإنتاج .

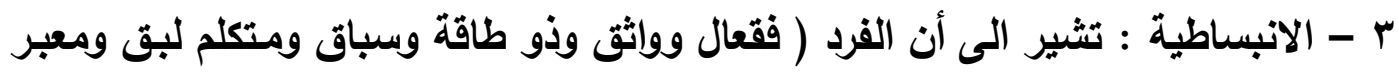
جيا واجتماعي وحسن المعشر ) .

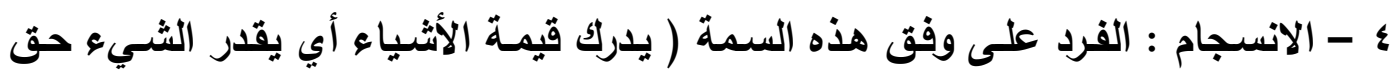

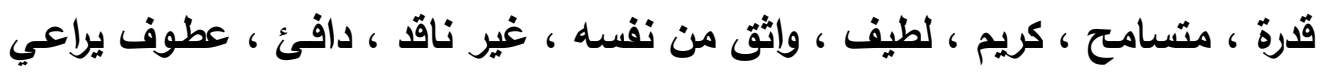

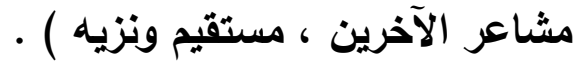

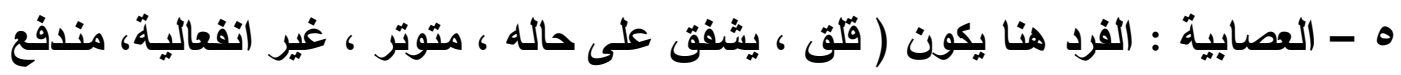

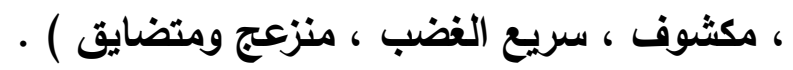
(Wiggens \& Tropnell , 1997, PP . 737 - 765) r r r r r الدراسات السابقة

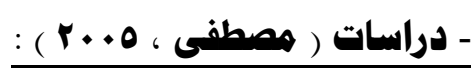
السـمات الخمسـة الكبرى في الثخصية لـاتى تدريسي الجامعة وعلاقتها ببعض المتغيرات . 
هبلة كلية التربية الرياضية .... جاهعة بغداد .... المبلد r. .... العدد ا

هدف الاراسـة الىى التعرف على مسـتويات السـمات الخمسـة الكبرى (العصسابية، الانبساطية ، الانفتاح ، الانسجام ، صحوة الضمير ) في شخصيات تلريسي جامعة صـلاح

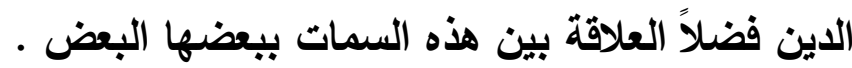
وفيما يخص الهدف الثاني التعرف على السمات والمتغيرات مثنل (العمر ، الجنس) وقد استخدم الباحث المنهج الوصفي وقد بلغ عدد أفراد العينة ( • ع ه) تدريسي اختيرت بالطريقة العمدية وياستخدام الوبائل الإحصائية المناسبة ـ أسفرت النتائج عن تميز أفراد عينـة البحث في السـمات (الانفتاح ، صـوة الضـير ، الانبسـاطية ، الانسـام ) وفيمـا يخص سمة العصابية فقد سجلوا أدنى مستوى عن بقية السمات بحيث لم تتجاوز المتوسط النظري للمقياس النظري ولم ترتقي الى مستوى المعنوية .

\section{البــابـ الثالهـث}

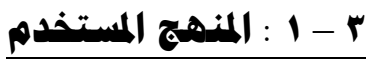

اسـتخدم الباحث المــهج الوصـفي بالطريقة الوصـي بالطريقة المسـية

وذلك لملائمته وطبيعة البحث الحالي •

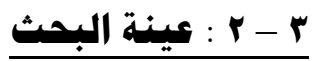

تم اختيـار عينـة البحث بالطريقة العمدية وتمثلت ببعض تدريسـي كليـات جامعة بغداد ( التربية الرياضية ، الصيدلة ، التربية للبنات ) والبـالغ (9 9 ) تلريسي، والجدول

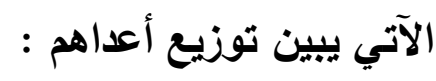




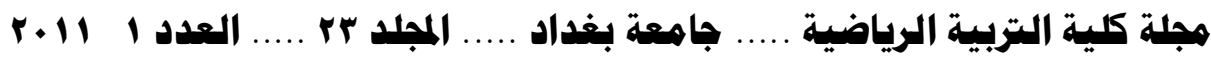

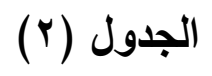

بين عدد أفراد عينة البحث

\begin{tabular}{|c|c|c|}
\hline 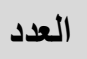 & الكلية & $ت$ \\
\hline$r v$ & التربية الرياضية & -1 \\
\hline rr & الصيدلة & $-r$ \\
\hline$r$. & التربية للبنات & $-r$ \\
\hline 79 & المجموع & \\
\hline
\end{tabular}

: r

نظراً الشـمولية الدراسـة على قياس الثخصية لذا فقد اعتمد الباحث الاستبيان

كوسيلة لجمع البيانات .

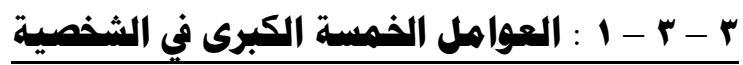

أن القياس المستخدم في قيـاس الشخصية هو مقيـاس العوامـل الخمسـة

الكبرى في الشخصية المعد من قبل كولا بيرك ـ (Goldberg , 1999)

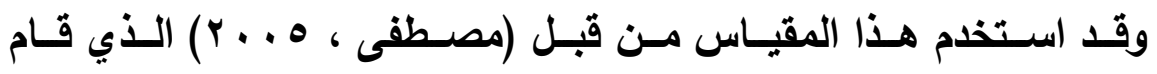

باستكمال جميع العمليات العلمية المطلويـة من صندوق ترجمة الفقرات وتمييزها وصدقها وثباتها وأن قائمسة العوامسل الخمسـة الكبرى في الشخصية يتكـون مـن ( • •) فقرة تقيس خمسة سمات (الانفتاح ، العصابية ، والانسجام ، والانبسـاطية ، وصحوة الضمير) ويواقع عشرة فقرات لكل سمة وصحح هذا القياس وفق بدائل خمسـة للإجابة تتراوح بين (خاطئ جداً ، وصحيح جداً) أي أن الدرجة تكون بين (1 - ه) للفقرات الإيجابية ويـالعكس للفقرات السلبية من هنا كان أعلى درجة لكل سمة ( • •) مقابل ( • 1) كأوطأ درجة بينما الوسط

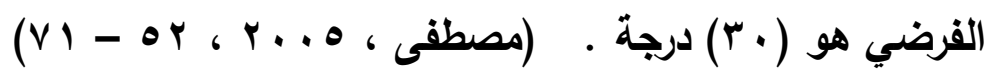




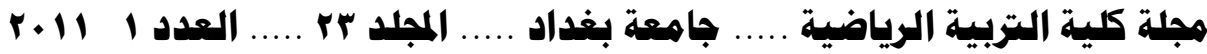



يعد الصدق أهم شروط الاختبار فالاختبار الصادق هو الأي ينجح في المقياس مـا

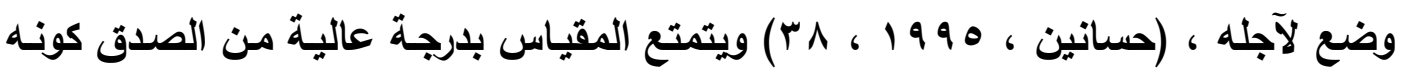

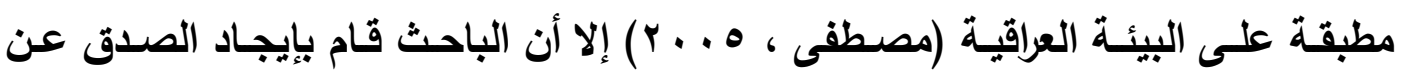
طريق عرض المقياس على مجموعة من الخير(**) المختصين في مجال العلوم التريويـة والنفسية والرياضية لبيان مدى صلاحية المقياس .

ويعد جمع الاستمارات من الخبراء وتحليلها فقد تم الحصول على نسبة

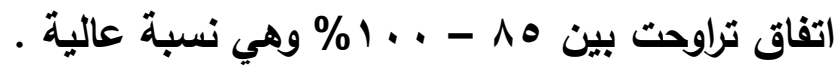

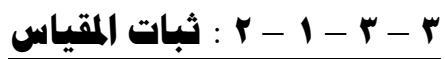

يعد ثبات المقياس من الخصائص السيكومترية المهمـة للمقاييس النفسية ويشير الحى اتسـاق درجات المقياس في قياس مـا يجب قياسـه بصورة منتظمسة (الخطيب

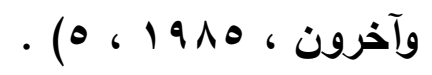

وقد اعتمد الباحث طريقة إعـادة الاختيـار لإيجـاد الثبات وهـي أن تعطي

الأداة النتائج نفسها إذا ما أعيد تطبيقها على الأفراد في الظروف نفسها ، (فرج ، 99V )

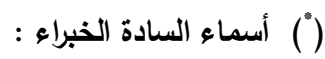

أ ـ م ـ ـ كامل عبد الحميد - علم النفس التريوي / كلية التربية / قسم علم النفس .

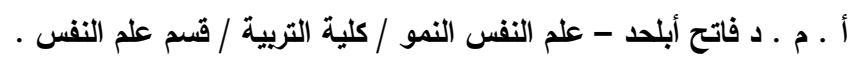

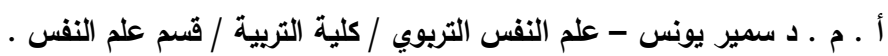

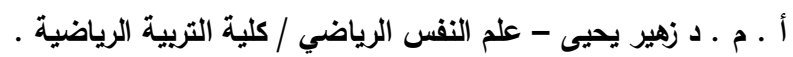

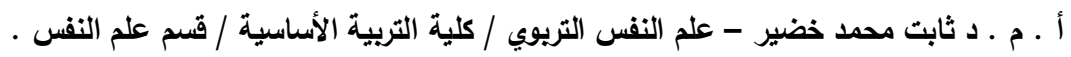


هبلة كلية التربية الرياضية .... جاهعة بغداد .... المبلد r. .... العدد ا

\section{البـاب الرابــع}

؟ - 1 : عرض وهناقشة النتائج

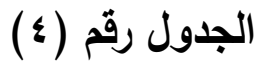

يبين الوسط الحسابي والانحراف المعياري وقيمة (ت) المحسوية بين المتوسط النظري للسمات في المقياس والسمات الشخصية لاى أفراد عينة البحث

\begin{tabular}{|c|c|c|c|c|c|c|}
\hline النتيجة & قالمحسوة (ت) & اللفوضيى & الالحيراف & الحسابي الوسط & القياس & الإلمصائية المعاتم \\
\hline معنوي & 0.711 & $r$. & $\varepsilon . \wedge Y \varepsilon$ & MT.rYA & درجة & الانفتاح \\
\hline معنوي & $\Lambda . \vee \vee q$ & r. & $7.17 \mathrm{~V}$ & $r q$. r $r \varepsilon$ & درجة & صحمة \\
\hline غير معنوي & $1 . V \mu \wedge$ & $r$. & 0.10 & rA.9YA & درجة & العصابية \\
\hline معنوي & $\varepsilon .90 r$ & $r$. & $r .9 \vee r$ & rY.Y $\{Y$ & درجة & الانبساطية \\
\hline & 19.19 & $r$. & $\varepsilon . q \vee r$ & $\& 1.0 \vee 1$ & درجة & الآسجام \\
\hline
\end{tabular}

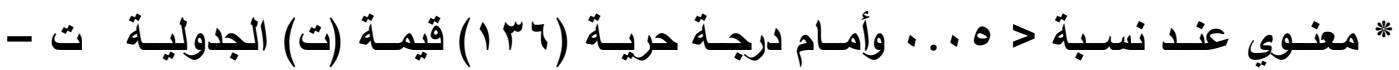
. .91

من الجدول (ع) يتبين أنه يوجد فروق ذات دلالة معنوية بين السمات الشخصية (الانفتاح ، صحوة الضمير ، الانبساطية ، الانسجام) والمتوسط الفرضي للمقياس ولصسالح السمات الشخصية بينما سمة العصابية لـم ترتقي الى مستوى الفرض للمقياس ولصساح السمات الشخصية بينما سمة العصابية لم ترتقي الى مستوى المعنوية وهذه النتيجة تتفق

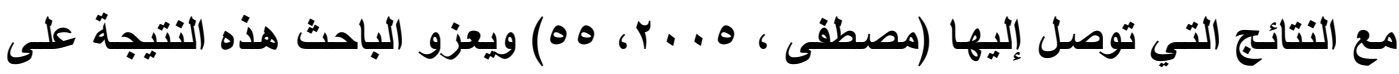

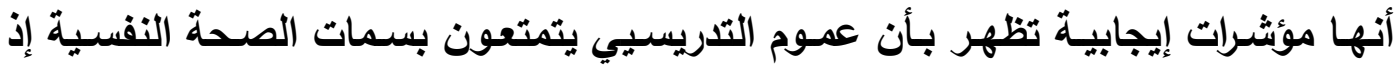
يثير كل من العالمين (Macraac \& Costa) الى أن أهم سمات الصحة النفسية هي الانسـام إذ من خلالها يتم الكشف عن حب الآخرين والتعاطف معهم ومن ثم صحوة 


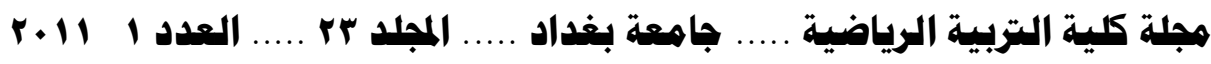

الضــمير التــي تثـــيز الــى الـــوعي والجديـــة والدافعيـــة والتصــميم فـــي العـــل .(Costa\&Macrae, 1992, 371)

أمسا صـفة الانبسـاطية فـن خصائصسها أنهـا تثـير الـى الفعاليـة وإلثقة المبـادرة والاهتمامات الاجتماعية ، حسن التكيف الاجتماعي ، والكفاء والتتظيم والشمولية.

(Wiggins \& Toppel, 1997)

وفيمـا يخص سـمة الانفتـاح السى كيفيـة رغيـة النـاس في خلق مـن التوافق بين

أفكارهم وفعالياتهم مع الأفكار والمواقف الجديدة. (Ewen, 1998 , 140$)$

وفيمـا يخص سمة العصـابية فإنها لـم ترتقي السى مستوى المعنويـة وهـي نتيجـة

منطقية إذا إنها السمات التي تدل على اضطرابات الشخصية .

(ن) الجدول

يبين اختبار التحليل التباين لإيجاد الفروق في سمة الانفتاح بين تدريسي كلية التربية

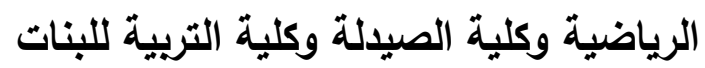

\begin{tabular}{|c|c|c|c|c|c|}
\hline النتيجة & قيمسة (ف) & المربعات متوسط مجموع & $\begin{array}{c}\text { مجموع المربعات } \\
\text { S.S.R }\end{array}$ & درجات الحرية & مصدر التباين \\
\hline \multirow{3}{*}{ معنوي } & \multirow{3}{*}{$1.79 \leq$} & $79 . r \wedge V$ & $1 \% \wedge . V V \varepsilon$ & $r$ & بين المجاميع \\
\hline & & $\varepsilon \cdot .900$ & rV.r..q & 79 & داخل المجاميع \\
\hline & & & 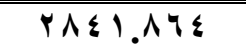 & 71 & المجموع الكلي \\
\hline
\end{tabular}

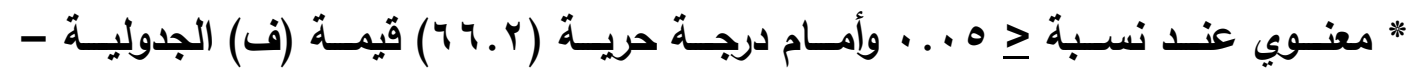
$.10 . \varepsilon$

يبين مـن الجدول (0) أن قيمـة (ف) المحسوية هـي أصغر مـن قيمتها الجدوليـة ويستدل الباحث من ذلك بأنـه لا يوجد فروق ذات دلالة مـة الانفتاح تدريسي كلية التربية الرياضية وكلية الصيدلة وكلية التربية للبنات . 


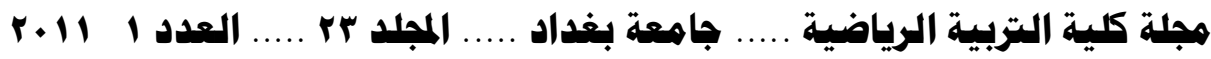

(7) الجدول (7)

يبين اختيار التحليل التباين لإيجاد الفروق في سمة صحوة الضمير بين تلريسي كلية التربية الرياضية وكلية الصيدلة وكلية التربية للبنات

\begin{tabular}{|c|c|c|c|c|c|}
\hline النتيجة & قالمحسوة (ف) & المربعات متوسط مجموع & $\begin{array}{c}\text { مجوع المربعات } \\
\text { S.S.R }\end{array}$ & $\begin{array}{l}\text { درجات الحرية } \\
\text {.D.F }\end{array}$ & مصدر التباين \\
\hline \multirow{3}{*}{ معنوي } & \multirow{3}{*}{$1.1 T \leq$} & ITV.rY & $Y V \leq .7 \varepsilon$ & $r$ & بين المجاميع \\
\hline & & 141.979 & $\vee 99.01$ & 79 & داخل المجاميع \\
\hline & & & AYYQ.YY & 71 & المجموع الكلي \\
\hline
\end{tabular}

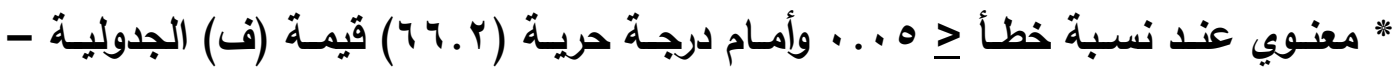
$. \mu .10 . \varepsilon$

يتبين من الجدول (†) أن قيمـة (ف) المحسوية هـي أصغر من قيمتها الجدوليـة وتوصل الباحث من ذلك بأنـه لا يوجد فروق ذات دلالـة معنويـة في سمة صحوة الضمير بين تدريسي التربية الرياضية وكلية الصيدلة وكلية التربيية للبنات.

$$
\text { (v) الجدول }
$$

يبين اختيار التحليل التباين لإيجاد الفروق في سمة العصابية بين تدريسي كلية التربية الرياضية وكلية الصيدلة وكلية التربية للبنات

\begin{tabular}{|c|c|c|c|c|c|}
\hline النتيجة & قيمة (ف) & المربعات متوسط مجموع & $\begin{array}{c}\text { مجموع المربعات } \\
\text { S.S.R }\end{array}$ & $\begin{array}{l}\text { درجات الحرية .D.F } \\
\text { د.F }\end{array}$ & التباين \\
\hline \multirow{3}{*}{ معنوي } & \multirow{3}{*}{$1 . \vee \wedge \varepsilon$} & 79.94 & 149.14 & $r$ & المجامين \\
\hline & & $r 9.99 r$ & Fqrq.07 & 79 & المجاميع \\
\hline & & & PVVq.\&Y & 71 & الكجموع \\
\hline
\end{tabular}

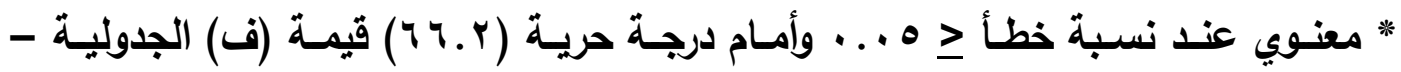
$. \mu .10 . \varepsilon$ 
هبلة كلية التربية الرياضية .... جاهعة بغداد .... المبلد r. .... العدد ا

يبين من الجدول (V) أن قيمة (ف) المحسوية هي أصغر من قيمتها الجدولية، ويستتتج الباحث مـن ذلـك بأنـه لا يوجد فروق ذات دلالـة معنويـة في سـمة العصـابية تدريسي كلية التربية الرياضية وكلية الصيدلة وكلية التربية للبنات .

$$
\text { (الجدول (1) }
$$

يبين اختيار التحليل التباين لإيجاد الفروق في سمة الانبساطية بين تدريسي كلية التربية الرياضية وكلية الصيدلة وكلية التربية للبنات

\begin{tabular}{|c|c|c|c|c|c|}
\hline النتيجة & قايمة (فحس) & $\begin{array}{l}\text { المربعات مجموع } 1 \text { M.S.R } \\
\text { M.S.R }\end{array}$ & $\begin{array}{c}\text { مجموع المربعات } \\
\text { S.S.R }\end{array}$ & درجات الحرية & مصدر التباين \\
\hline \multirow{3}{*}{ معنوي } & \multirow{3}{*}{10.409} & Pपะ.० & VYq & $r$ & بين المجاميع \\
\hline & & TYVTY & $1004 . \mathrm{KV}$ & 97 & داخل المجاميع \\
\hline & & & r $q^{\prime} \odot . r r v$ & 71 & المجموع الكلي \\
\hline
\end{tabular}

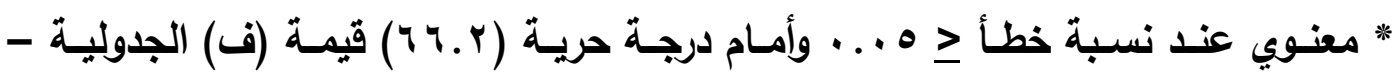
$.10 . \varepsilon$

يتبين من الجدول (^) أن قيمـة (ف) المحسوية هي أصغز من قيمتها الجدوليـة وتوصل الباحث مسن ذلك بأنسه يوجد فروق ذات دلالـة معنويـة في سمة الاتبسـاطية بين تدريسي كلية التربية الرياضية وكلية الصيلة وكلية التربية للبنات ويغية التحقق لصالح من كانت هذه الفروق لجأ الباحث الى استخدام اختيار قيمة أقل فرق معنوي (L.S.D) . 
هبلة كلية التربية الرياضية .... جاهعة بغداد .... المبلد r. .... العدد ا

(9) الجدول

يبين دلالة الفروق في الأوساط الحسابية لسمة الانبساطية بين تدريسي كلية التربية الرياضية وكلية الصيدلة وكلية التربية للبنات التئل

\begin{tabular}{|c|c|c|c|c|}
\hline قيمة (ف) & التربية الرياضية & التربية للبنات & الصيالة & الكلية \\
\hline \multirow{5}{*}{$r .0 \leqslant 4$} & Wo.乏.V=س & س' & س' & \\
\hline & \multirow{2}{*}{ - } & \multirow{2}{*}{$\varepsilon .10 \mathrm{~V}$} & \multirow{2}{*}{$\varepsilon . \Delta r \wedge$} & التربية الرياضية \\
\hline & & & & 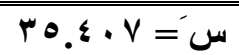 \\
\hline & \multirow{2}{*}{ - } & \multirow{2}{*}{ - } & \multirow{2}{*}{$\cdot r \wedge l$} & التربية للبنات \\
\hline & & & & س'=0.r. \\
\hline
\end{tabular}

1 - أن الفرق بين تلريسي كلية التربية الرياضية وكلية الصيالة في سمة الانبسـاطية

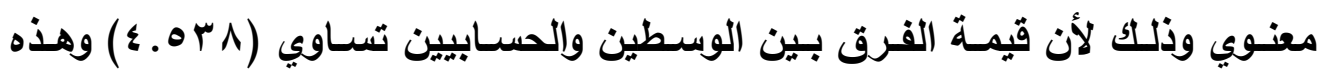
القيمة أكبر من قيمة (I.S.D) ولمصلحة تدريسي كلية التربية الرياضية .

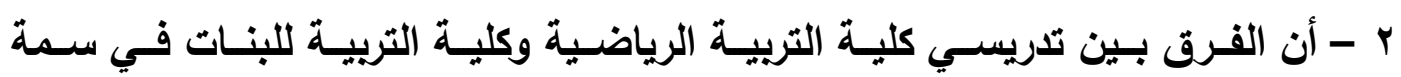

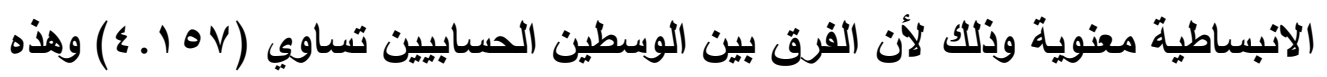
القيمة أكبر من قيمة (L.S.D) ولمصلحة تدريسي كلية التربية الرياضبة. ب - لا يوجـ فرق معنـوي بين تدريسـي كليـة الصسيلة وكليـة التربيـة للبنـات في سـمة

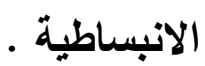




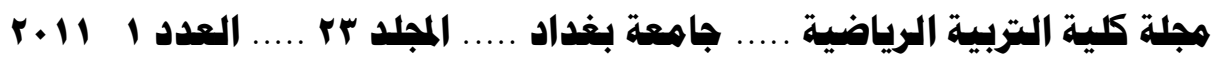

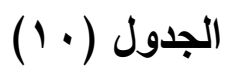

يبين اختيار التحليل التباين لإيجاد الفروق في سمة الانسجام بين تدريسي كلية التربية الرياضية وكلية الصيدلة وكلية التربية للبنات

\begin{tabular}{|c|c|c|c|c|c|}
\hline النتيجة & قيمسة (ف) & المربعات متوسط مجموع & $\begin{array}{c}\text { مجموع المربعات } \\
\text { S.S.R }\end{array}$ & $\begin{array}{c}\text { درجات الحرية } \\
\text {.D.F }\end{array}$ & التباين \\
\hline \multirow{3}{*}{ غعنوي } & \multirow{3}{*}{$17.1 \leq 0$} & $\{r V . r 1$ & $\Lambda V \varepsilon . \varepsilon Y$ & $r$ & المجاميع \\
\hline & & $r v . \wedge$ & IVAV.rr & 79 & المجاميع \\
\hline & & & หчצI.V0 & 71 & الكليموع \\
\hline
\end{tabular}

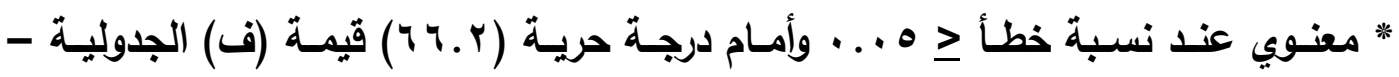
$.10 . \varepsilon$

يتبين من الجدول ( • 1) أن قيمة (ف) المحسوية هي أصغر من قيمتها الجدولية ويستـل الباحث مسن ذلك بأنـه توجد فروق ذات دلالـة معنويـة في سـمة الانسـام بين تدريسي كلية التربية الرياضية وكلية الصيالة وكلية التربية للبنات ويغية التحقق لصالح من كانت هذه الفروق لجأ الباحث الى استخدام قيمة أقل فرق معنوي (L.S.D) . 
هبلة كلية التربية الرياضية .... جاهعة بغداد .... المبلد r. .... العدد ا

\section{(الجدول (1) - (1) - (1) (1)}

يبين دلالة الفروق في الأوساط الحسابية لسمة الانسجام بين تدريسي كلية التربية الرياضية وكلية الصيدلة وكلية التربية للبنات (L.S.D)

\begin{tabular}{|c|c|c|c|c|}
\hline قيمة أقل فرق & التربية الرياضية & كلية الصيدلة & التربية للبنات & الكلية \\
\hline \multirow{5}{*}{$r . \vee \wedge \wedge$} & س'= & mó = r r & س" = •. & \\
\hline & \multirow[t]{2}{*}{-} & \multirow[t]{2}{*}{$\varepsilon . \varepsilon$} & \multirow[t]{2}{*}{$\varepsilon .7 r$} & الرياضية \\
\hline & & & & rq. س = \\
\hline & \multirow{2}{*}{-} & \multirow{2}{*}{-} & \multirow{2}{*}{$\because r^{\top}$} & الصيالة \\
\hline & & & & س' \\
\hline
\end{tabular}

إن الفـرق بـين تلريسـي كليـة التربيـة الرياضسية وكليـة التربيـة للبنـات في سـمة الانسـام معنوي وذلك لأن قيمة الفرق بين الوبطين الحسـابيين تسـاوي (Y Y ـ ؛ ) وهذه القيمة أكبر من قيمة (L.S.D) ولمصلحة تدريسي كلية التربية الرياضية . أن الفرق بين تدريسي كلية التربية الرياضية وكلية الصيدلة في سمة الانسجام معنوي وذلك لأن الفـرق بين الوسطين الحسـابيين تسـاوي (ع. ع) وهذه القيمـة أكبر مـن

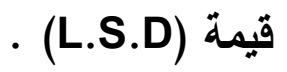
لا يوجد فرق معنوي بين تدريسي كليـة الصيدلة وكليـة التربية للبنـات في سمة - 1 الانسجام وفيما يخص الجداول (1 ، 9 ، ، 1 ، 1 1 1) فإن الباحث يعزو أن التوصل الى هذه التتائج التـي تثـير بـأن تدريسـي كليـة التربيـة الرياضسية تميزوا بسـمتى (الانبسـاطية والانسجام) يعود السى طبيعة العوامل التي أثرت في شخصيتهم وذلك من خـلال المواقف 


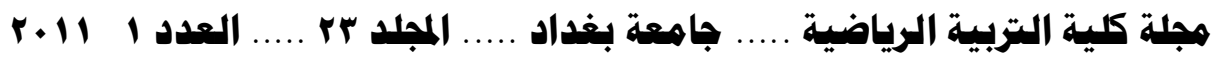

التي ترضوا لها ليس فقط على الصعيد المهني ولكن على الصسعيد الرياضي والعمل في

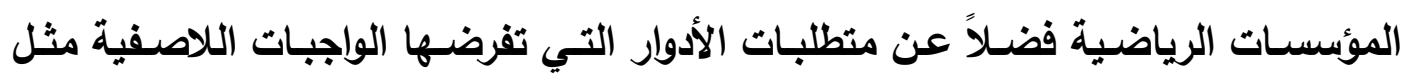

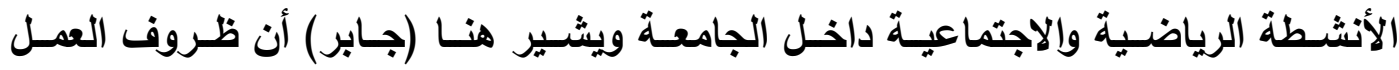

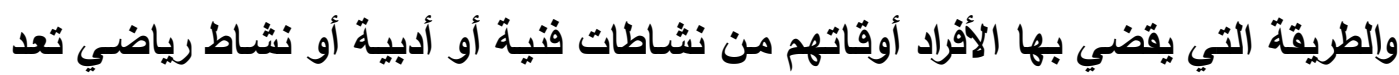

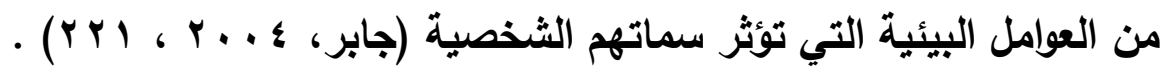

\section{البــاب الخاهـسـ}

- 1 : الاستنتتاجات

1 - يتمتع تدريسيو كلية الرياضية وكلية الصيدلة وكلية التربية للبنات بسمات (الانفتاح ،

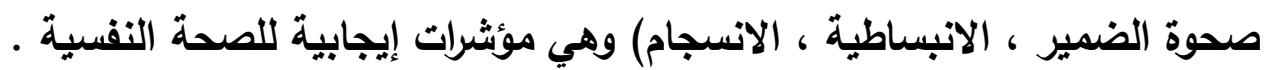

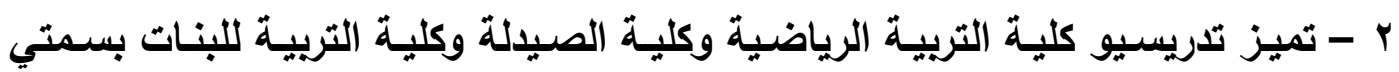

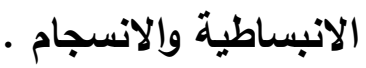

r - لا يوجد فروق السمات الثخصية بين تدريسيو كلية الصيدلة وكلية التربية للبنات .

1 - اعتمـاد مقياس : التوصيات السمات الخمسة الكبرى في الثخصية في البحوث التي تعمل في مجال علم نفس الثخصية . r - تنمية السمات الإيجابية في الثخصية لدى تدريسي كليات جامعة بغداد والحد من السمات السلبية .

r - ضرورة إجراء دراسات مستقبلية على عينات أكبر من التّريسي ولمختلف الكليات. 


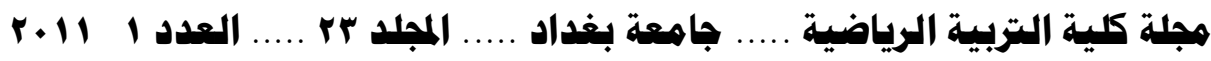

\section{المسادر العربيسة والأجنبيسيسة}

ه أبو جادو ، صالح محمد علي ( . . . F) : علم النفس التربوي ، طץ ، دار المسيرة للنشر والتوزيع ، عمان الأردن .

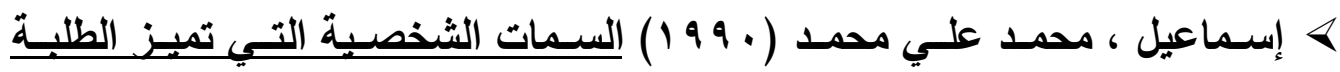
المتفوقين على غير المتقوقين في نهاية المرحلة الثانوية عند طلبة مدارس حوض البقعة في محافظة البلقاع ، رسالة ماجستير غير منشور ، الأردن •

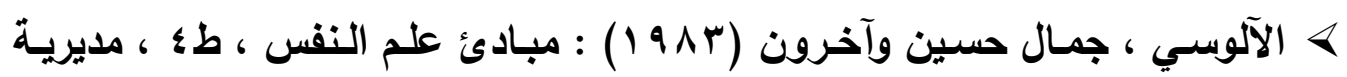

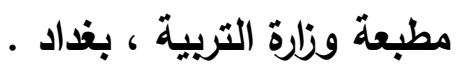

ه التكريتي ، وديع ياسبن والعبيدي ، حسن محمد (9999 19) : التطبقات الإحصائية واستخدامات الحاسوب في بحوث التربية الرباضية ، دار الكتب للطباعة وإلنشر ،

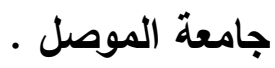

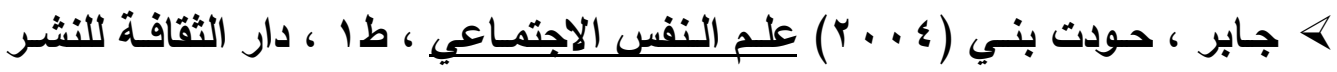
والتوزيع عمان ، الأردن . > جاسـم ، عبد السـلام جودت (9 9 ( ) ) : أثر العقويـة في أحداث السـوك العدواني وعلاقته بيعض أسـاليب المعاملة الوالدبـة ، رسـالة ماجستير غير منشورة ، كليـة

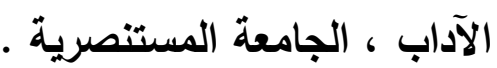

ه جلال ، سعد وعلاوي ، محمد حسن (9V7 I ) : علم التفس التربوي الرياضس، طه ، دار المعارف القاهرة . - ماري

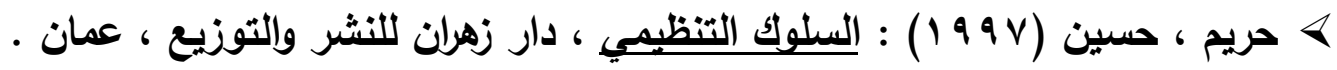

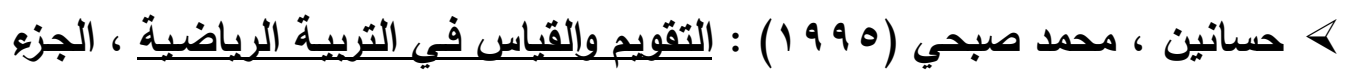
الأول ، طץ ، دار الفكر للطباعة والنشر والتوزيع ، عمان . 


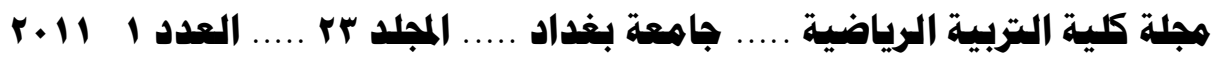

ه الخطيب ، أحمد وآخرون (0^9 1) : البحث والتقويم التربوي ، دار المستقبل عمان •

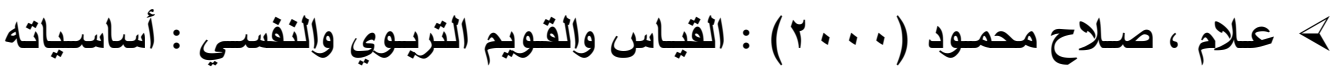
وتطبيقاته وتوجيهاته المعصرة ، طا ، دار الفكر العربي القاهرة ، مصر . ه علاوي ، محمد حسن (1991 ) : مـخل في علـم النفس الرياضسي ، طا ، مركز لكتاب للنشر ، القاهرة .

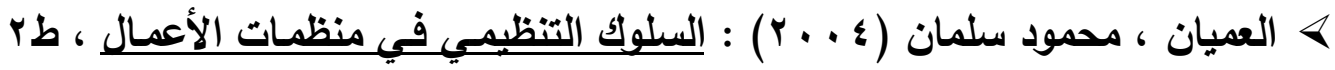
، دار وائل للنشر والتوزيع ، الكويث . ه العنزي ، فريح عويد (991 (9 ) : علم نفس الثخصية ، طا ، مكتبة الفلاح للنشر والتوزيع ، الكويت . ه فرج ، صفوت (99V 1 ) ) القياس النفسي ، ط" ، الأنجلو مصرية ، القاهرة . > فرنتانا ، ديفيا (9 (99) ) الشخصية والتربية ، ترجمة عبد الحميد يعقوب جبرائيل وصلاح محمد نوري ، مطابع التعليم العالي ، جامعة صلاح الدين ، أربيل .

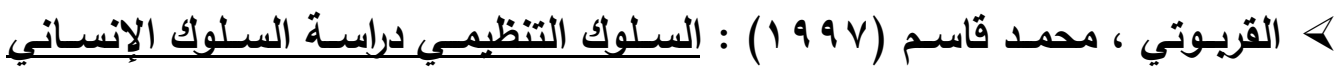
الفردي والجماعي في المنظمات الإدراية ، طץ ، المطابع المركزية عمان .

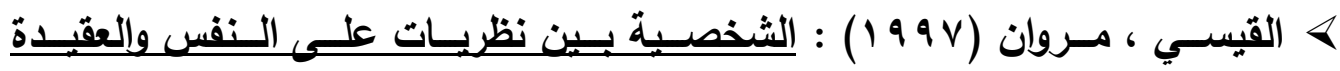
الإسلامية ، مجلة أبحاث اليرموك ، سلسلة العلوم الإنسانية والاجتماعية ، المجلد ع ا ، العدد I.

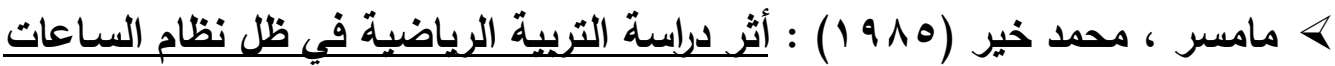
المعتمدة على سمات شخصبة الطالب ، مؤتمر الرياضة للمجتمع في الدول النامية ، جامعة حلوان ، مصر ، 
هجلة كلية التربية الرياضية .... جاهعة بغداد .... المبلد r. .... العدد ا

ه مراد ، جمال الدين عبد العزيز (9 9 1 ) : دراسـة مقارنـة بين لاعبي كرة اليد وكرة المـاء في بعض السـمات الشخصسية، مجلة دراسـات ويحوث ، المجلد العاشـر ، العدد الثالث ، جامعة حلوان ، مصر .

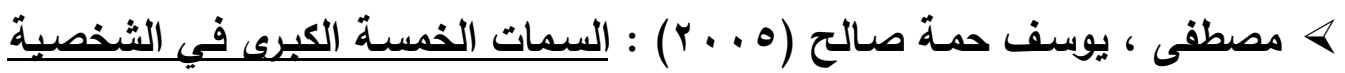
للدى تلدريسي الجامعة وعلاقتهـا بـعض المتغيرات ، مجاة العلوم النفسية ، مركز البحوث النفسية والتربوية ، جامعة بغداد . ه المغريسي ، كامـل محمد (9909 190) : السـلوك التنظيمسي مفـاهيم وأسسس سلوك الفرد والجماعة في التنظيم، طץ ، دار الفكر للنشر والتوزيع ، عمان . ه منـال ، كامـل مصـطفى (ب99 99 ) : علاقة السـمات الشخصـية ويعض القياسـات الجسمية بالتعلم في درس السباحة ، رسالة ماجستير غير منشورة ، كلية التربية

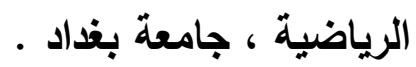

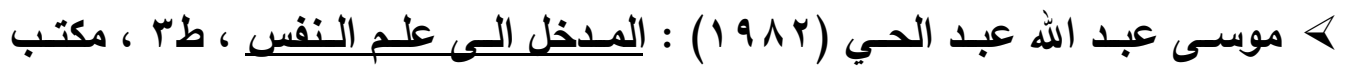

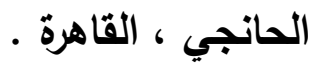

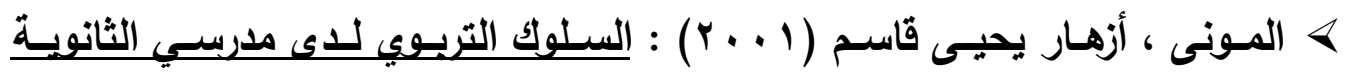
وعلاقتها بسمات الثخصبة والتأهيل التربوي ومدة الخدمة ، رسـالة ماجستير غير منشورة ، كلية التربية ، جامعة الموصل . ه الوقفي ، داخلي (19 9 1 ) : مقدمة في علم النفس ، طب ، عمان الأردن . ه يونس ، وليد ذنون (9999 199) : دراسة مقارنة في السمات الشخصية بين النلاعبين المتقدمبن في الألعاب الجماعبة ، رسبالة ماجسيتر غير منشورة ، كليـة التربيـة الرياضية ، جامعة الموصل .

$>$ Lahey, Benjamin , B (2001) psychology : an introduction (7 edition) Mc Craw Hill USA . 


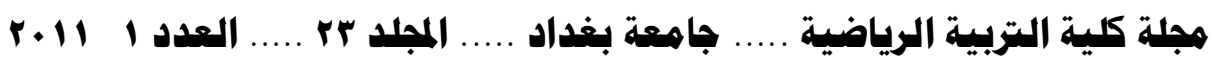

$>$ Wiggins i.s \& Trapnell pd (1997) personality structure : the return of the big five Hand book of personality psychology.

$>$ Bandura, a (1971) social leaning theory, marisstown, $n, t$ learning press, New York.

$>$ Gold berg, L, r, \& Gohnson, g, a. (1999), www .

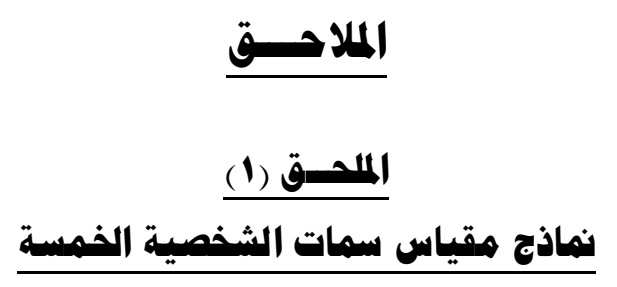

$$
\begin{aligned}
& \text { جامعة بغداد } \\
& \text { كلية التربية للبنات } \\
& \text { الأستاذ العزيز ... } \\
& \text { تحية طبية }
\end{aligned}
$$

مسن أجل الهـف العـام مسن إجـرار البحوث، يرجى تفضـلكم الإجابـة على نمـوذج مقيـاس سمات الثخصية الخمسة، ويمـا يـتلاعم مـع شخصيتك في الوقت الحسالي، خدمـة لرسالة البحث العلمي... - م

\section{شاكرين تعاونكم}

\section{الباحث \\ سراب شاكر سهيل}




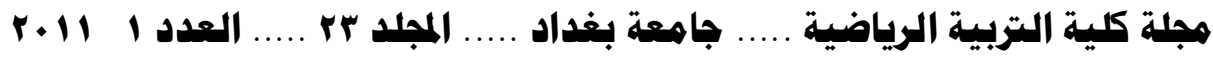

الإقيــــاس

\begin{tabular}{|c|c|c|c|c|c|c|}
\hline صحيح & صليلاً & لا خاطئ & خاطئ & خاطئ & الفقـرات & $ت$ \\
\hline & & & & & أميل الى العلاقات مع الناس المحافظين & 1 \\
\hline & & & & & أنا ذو مزاج متقلب دائماً & r \\
\hline & & & & & |لا أتضايق بسهولة من الأثشياء & r \\
\hline & & & & & لدي دوافع كاملة من الثك عن الآخرين & $\varepsilon$ \\
\hline & & & & & |تمتع بسماع أفكار جليدة & • \\
\hline & & & & & أؤمن بأهمية الفن & 7 \\
\hline & & & & & أمتلك خيالا خصباً & $\mathrm{v}$ \\
\hline & & & & & |أسخر حياتي من أجل المجموعة & $\wedge$ \\
\hline & & & & & ماهر في التعامل مع المواقف الاجتماعية & 9 \\
\hline & & & & & أنا دائماً متهيئ & 1. \\
\hline & & & & & أخطط واتثبث بخططي & 11 \\
\hline & & & & & ل ألا أحب نفسي & ir \\
\hline & & & & & المترم الآخرين & ir \\
\hline & & & & & | أهين الناس & $1 \leq$ \\
\hline & & & & & أصف خبراتي نوع ما بالبلاد & 10 \\
\hline & & & & & نادراً ما أشعر بتعكر المزاج & 17 \\
\hline & & & & & لا أرغب أن أجلب التباه الآخرين عن نفسي & iv \\
\hline & & & & & أنفذ خططي & 11 \\
\hline & & & & & لا أهتم لأفكار المجردة & 19 \\
\hline
\end{tabular}




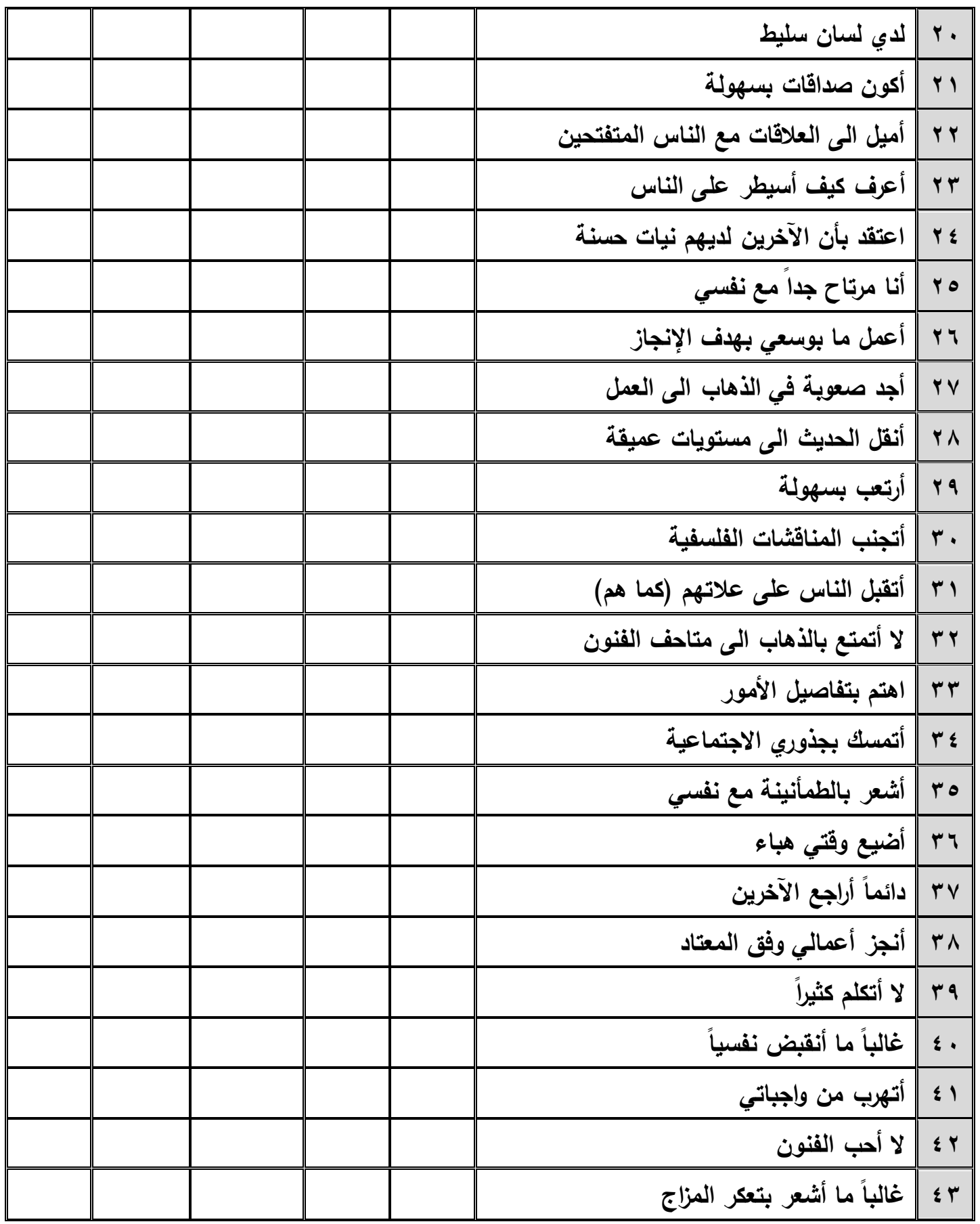




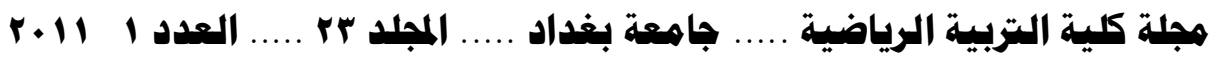

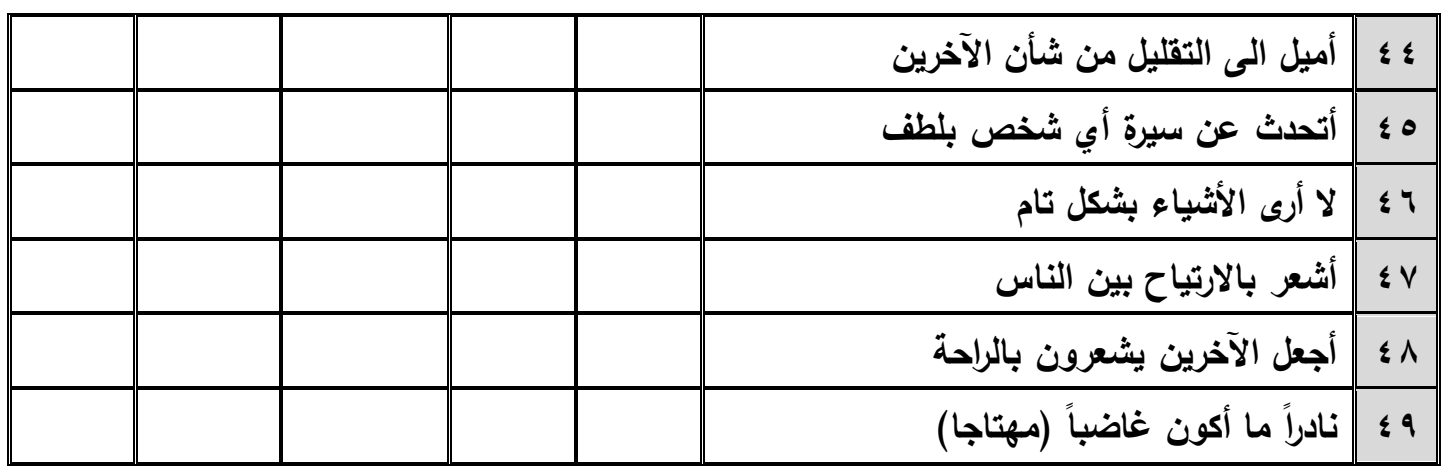

